\title{
COST BENEFIT ANALYSIS OF A DG INTEGRATED SYSTEM: CASE STUDY
}

\author{
Ch. V. S. S. SAILAJA*, P. V. N. PRASAD ${ }^{* *}$ \\ *Department of Electrical and Electronics Engineering, \\ Vasavi College of Engineering, Hyderabad, India, E-mail: sailajacvss@gmail.com \\ ${ }^{* *}$ Department of Electrical Engineering, University College of Engineering, OU, Hyderabad, India, \\ E-mail: pvnprasad09@gmail.com
}

\begin{abstract}
Distributed Generation is capable of meeting the load of the consumers partially or completely. Depending on the type of DG involved it can be operated in interconnected mode and islanded mode. The availability of numerous alternatives present for the DG technologies and large initial investments necessitates a detailed cost benefit analysis for the implementation of DG technologies. In this work an attempt has been made to study the costs involved in implementing the DG technologies. A practical system having two kinds of distributed generation i.e., Diesel Generator and solar photovoltaic system for its back up purpose is considered. A detailed cost analysis of the two DG technologies is carried out.
\end{abstract}

Keywords: Diesel Generator, Solar Photovoltaic System (SPV), utility grid, Energy Costs

\section{INTRODUCTION}

Distributed generation is electricity production that is on site or close to the load center and is interconnected to the utility distribution system. Distributed generation can allow utilities to defer transmission and distribution upgrades [1]. By placing these alternative energy sources, and other smaller traditional energy sources, on the distribution power system, will lead to the development of a new model related to distributed generation (DG). Microturbines, wind and solar energy, fuel cells, small gas turbines are a few among the different DG technologies. DG can be used in an isolated way, supplying the consumer's local demand, or in an integrated way, supplying energy to the remaining of the electric system. This local generation reduces the need for large-scale utility projects [1]. DG can overcome the deficiencies in the transmission system and therefore prove beneficial for both consumers and utilities especially where central generation is not practicable. DG can provide many benefits such as voltage support, improved utility system, reliability, loss reduction, transmission and distribution capacity release and better power quality [2] Accomplishing these positive effects require large investments in terms of cost of DG, installation and maintance costs. In this paper a practical distribution system of Vasavi College of Engineering is considered for cost effective evaluation of DG integration. Vasavi college of Engineering has utility supply of connected load 650 kVA to meet its load requirement. Prior to the installation of solar power generation, the scheduled and forced outages are met by Diesel Generators set of one $625 \mathrm{kVA}$, one $500 \mathrm{kVA}$ and one $125 \mathrm{kVA}$. In addition to the capital cost of Diesel generators, the maintenance cost of Diesel Generator was high. Diesel Generators were operated whenever there is an interruption in the utility supply. The maximum demand of the load cannot be decreased as the load is met by the diesel generator in the event of interruptions only. With the installation of Solar power the maximum demand agreement with the utility is reduced and the diesel requirement also reduced. In this work a detailed cost analysis of these two ways of meeting the load requirement of the selected network is presented. The technical details and the single line diagram of the selected network is given in Section 2, the diesel requirement and the cost evaluation details in meeting the load using diesel generator are presented in Section 3. Section 4 discusses the cost and technical details of the solar power installed. The comparison of the two methodologies is specified in Section 5 and the conclusions are presented in Section 6.

\section{TEST SYSTEM AND SINGLE LINE DIAGRAM}

The distribution system of Vasavi college of Engineering is selected for comparing the cost of different DG technologies. The college was established 1981 and is one of the top engineering colleges in the state of Telangana. There are seven engineering departments which have major laboratories. It has a total maximum demand of $650 \mathrm{kVA}$ and a power factor of 0.9 is maintained with the help of a capacitor bank of $170 \mathrm{kVAR}$ (1X50 kVAR, 4X25 kVAR and 2X10 kVAR). The single line diagram of the system is shown in Fig. 1.

The power requirement of the college is met through a $650 \mathrm{kVA}, 11 / 0.415 \mathrm{kV}$ transformer. To meet the load in the event of scheduled and forced outages, three DG sets of capacities $625 \mathrm{kVA}, 500 \mathrm{kVA}$ and $125 \mathrm{kVA}$ are installed.

\section{COST EVALUATION FOR DIESEL GENERATOR}

Diesel Generators of capacities $625 \mathrm{kVA}, 500 \mathrm{kVA}$ and $125 \mathrm{kVA}$ are installed for providing back up to the college in the event scheduled and forced outages. 625 kVA Diesel Generotor is connected to Ramanujan block, C.V.Raman Block and J.C.Bose Block for backup requirements. $500 \mathrm{kVA}$ diesel generator set is connected Viswesrayya block, Sarvepally Radha Krishnan Block, Mechanical, Civil, Laboratories and Canteen. A bus coupler transfers the entire load to either $625 \mathrm{kVA}$ DG set or to $500 \mathrm{kVA}$ DG set. The $125 \mathrm{kVA}$ is used during 


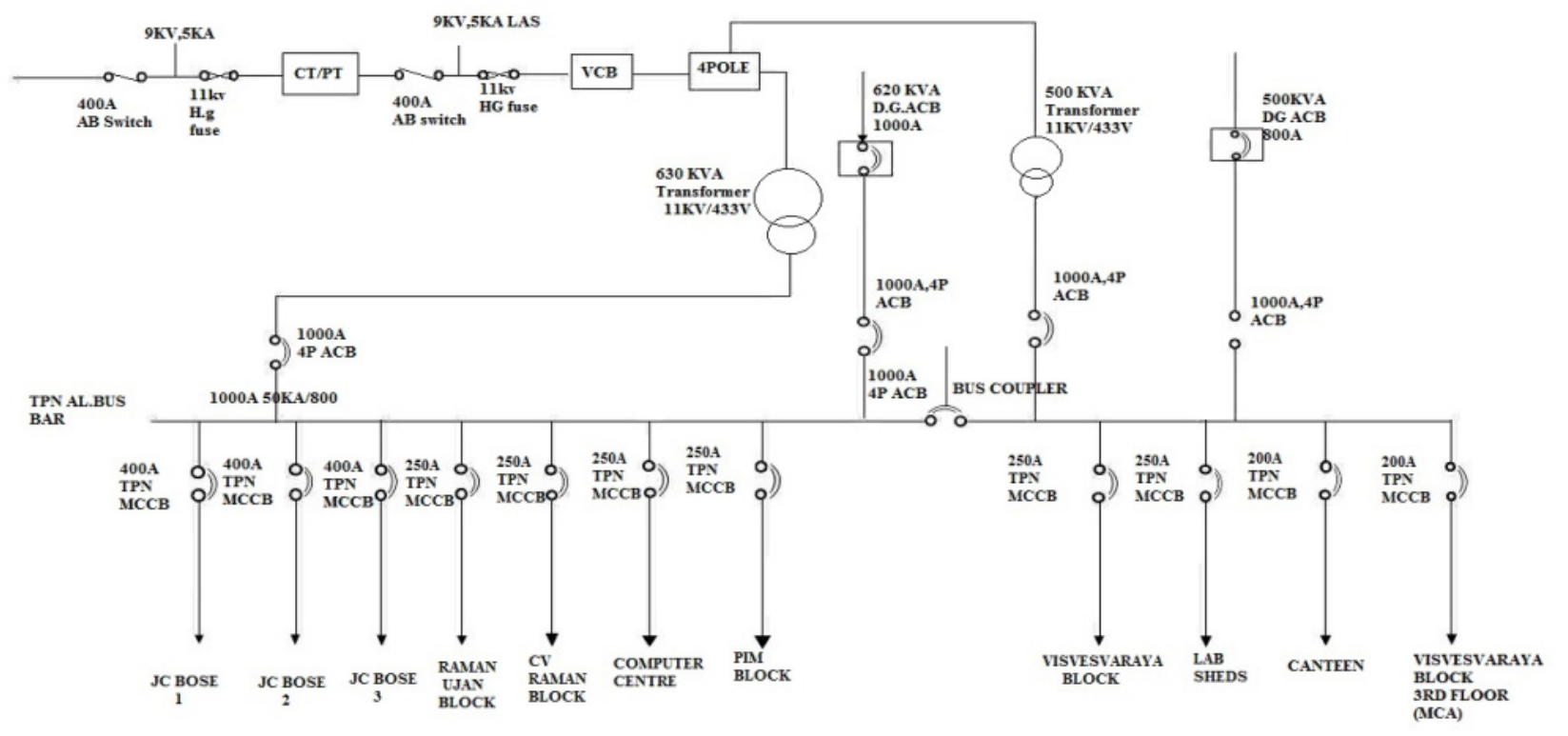

Fig. 1 Single Line diagram of Vasavi College of Engineering

holidays and after working hours of the college for illumination (Street Lighting).

The number of units generated, quantity and cost of diesel consumed in an year i.e, from October 2013 to September 2014 is given in Table 1.

Table 1 Diesel Consumption and cost in an year

\begin{tabular}{|c|c|c|c|c|}
\hline $\begin{array}{c}\text { S. } \\
\text { No }\end{array}$ & Month & $\begin{array}{c}\text { Diesel } \\
\text { Consumption } \\
\text { (liter) }\end{array}$ & $\begin{array}{c}\text { Total } \\
\text { Number of } \\
\text { Diesel Units } \\
(\mathrm{kWh})\end{array}$ & $\begin{array}{c}\text { Total } \\
\text { Cost of } \\
\text { Diesel } \\
(\mathrm{Rs})\end{array}$ \\
\hline 1 & October & 2003 & 5624 & 112168 \\
\hline 2 & November & 796 & 2013 & 46056 \\
\hline 3 & December & 1060 & 2722 & 62084 \\
\hline 4 & January & 295 & 491 & 17278 \\
\hline 5 & February & 1435 & 3639 & 85827 \\
\hline 6 & March & 1820 & 5354 & 109964 \\
\hline 7 & April & 1797 & 5530 & 108593 \\
\hline 8 & May & 1183 & 3505 & 73074 \\
\hline 9 & June & 1273 & 3544 & 78663 \\
\hline 10 & July & 1340 & 2708 & 84447 \\
\hline 11 & August & 2197 & 5455 & 139795 \\
\hline 12 & September & 871 & 2154 & 55422 \\
\hline
\end{tabular}

The total number of units produced by the diesel generators in the period considered from the above table are 42,739. Diesel unit refers to the kilo-watt-hours produced by the Diesel generator. Total number of diesel units is the output of the Diesel Generator in $\mathrm{kWh}$ during its period of operation. The quantity of diesel consumed in this period was 16,070 liters. The total expenditure on diesel during this period is Rs.9,73,341/-. (Rs refers to Rupees in INR and 1 Rupee is equal to 0.02 USD $₹ 1.00=$ US $\$ 0.02$ )

\section{COST EVALUATION FOR PHOTOVOLTAIC SYSTEM}

The Vasavi college of Engineering has five buildings namely Viswesrayya block, Ramanujam block, C.V.
Raman block, Sarvepalli Radha Krishnan block and Jagdish Chandra Bose block. The rooftop solar PV plant was erected on J.C.Bose block and Viswesrayya block. $125 \mathrm{kWp} \mathrm{SPV} \mathrm{is} \mathrm{installed} \mathrm{on} \mathrm{J.C.Bose} \mathrm{block} \mathrm{in} \mathrm{the}$ available 41.53 Sq.mt area and an area of 25 Sq.mt is available on Viswesrayya block on which $75 \mathrm{kWp} \mathrm{SPV} \mathrm{is}$ installed. The grid interactive roof top solar PV system generally comprises the following equipment.

- Solar PV Modules

- Inverter Mounting Structure

- $\quad \mathrm{AC}$ and DC Cables

- Earthing equipment/material

- Junction Boxes

- Lightning protection equipment

\subsection{Scheme of Grid Interactive Roof top Solar PV system}

The single line diagrams of the SPV installed on JC Bose block is shown in Fig. 2 and that of the Viswerayya block is given in Fig. 3. The installed SPV has no battery backup and it requires reference voltage for synchronization with the grid. Thus the SPV is operated in unification of either grid supply or Diesel generator supply. Therefore the output of the inverters is connected to the common bus to which the utility supply and diesel generators are interconnected.

It was estimated that there will be an annual energy generation of 300-360 MWh .The PV Modules produce 1000 watts per sq.mt on a standard sunny conditions this is called a peak sun. Less than one peak sun reduces the module current proportionately. The monthly energy generation from the SPV power plant has been presented in Table 2 and is represented graphically in Fig. 4. It can be observed from the figure there is a large variation in the number of units being generated as the generation of solar energy is dependent on solar radiation at an optimum temperature of $25^{\circ} \mathrm{C}$. 


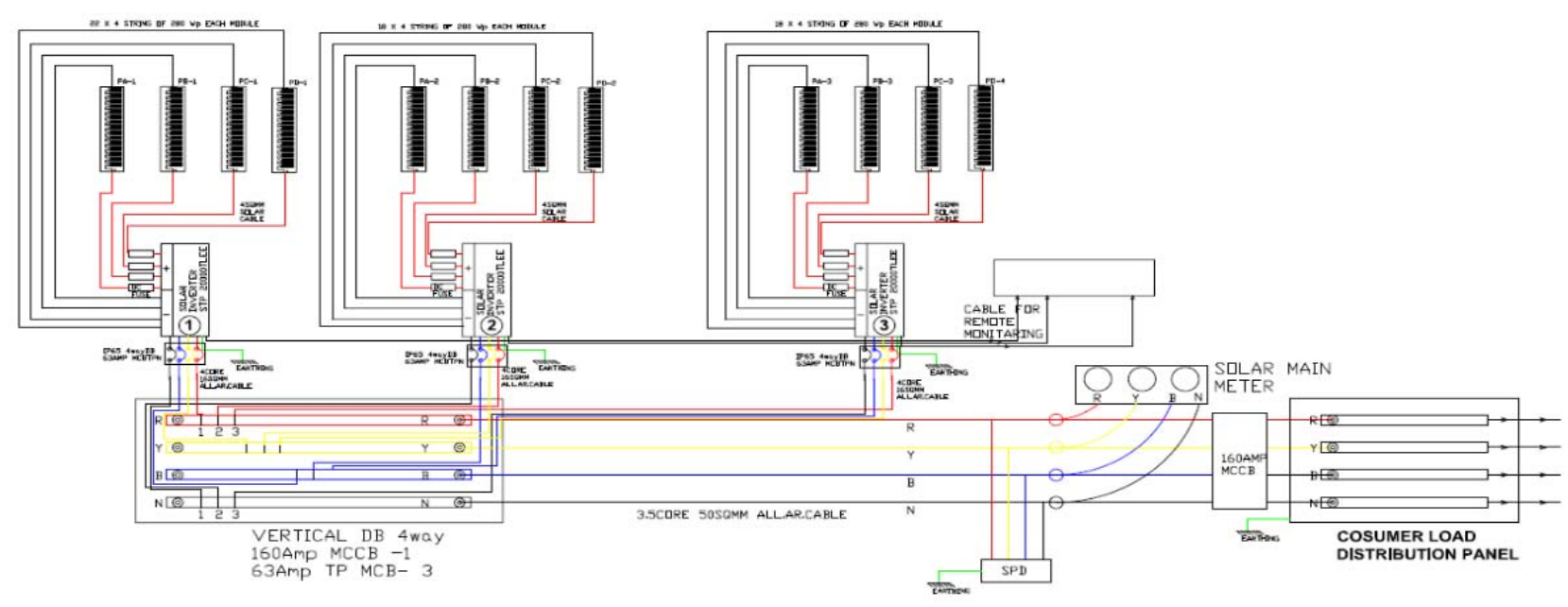

Fig. 2 Single Line diagram of SPV on JC Bose Block

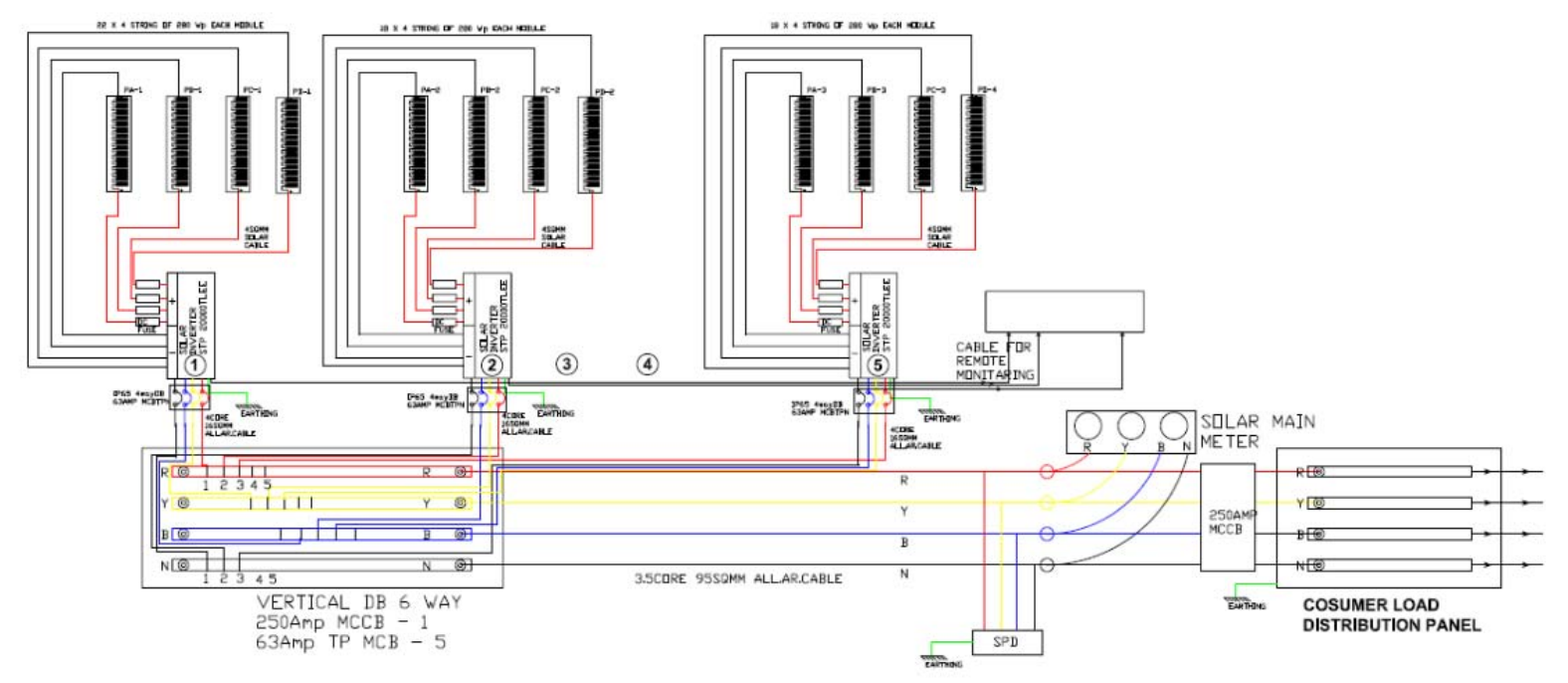

Fig. 3 Single line Diagram of SPV on Viswesrayya Block

Table 2 Solar Power Generation

\begin{tabular}{|c|c|c|}
\hline $\begin{array}{c}\text { S. } \\
\text { No }\end{array}$ & Month & $\begin{array}{c}\text { Number of units } \\
\text { generated }\end{array}$ \\
\hline 1 & November & 23723 \\
\hline 2 & December & 21100 \\
\hline 3 & January & 24385 \\
\hline 4 & February & 28582 \\
\hline 5 & March & 23604 \\
\hline 6 & April & 26090 \\
\hline 7 & May & 27872 \\
\hline 8 & June & 25811 \\
\hline 9 & July & 6770 \\
\hline 10 & August & 8240 \\
\hline 11 & September & 12890 \\
\hline 12 & October & 23630 \\
\hline
\end{tabular}

With the addition of Solar Photovolatic System, the amount of diesel consumed is decreasd considerably. Diesel Genearators are operated when there are outages on the grid. The pattern of diesel consumption and the utility bill after the SPV integration is shown in Table 3.

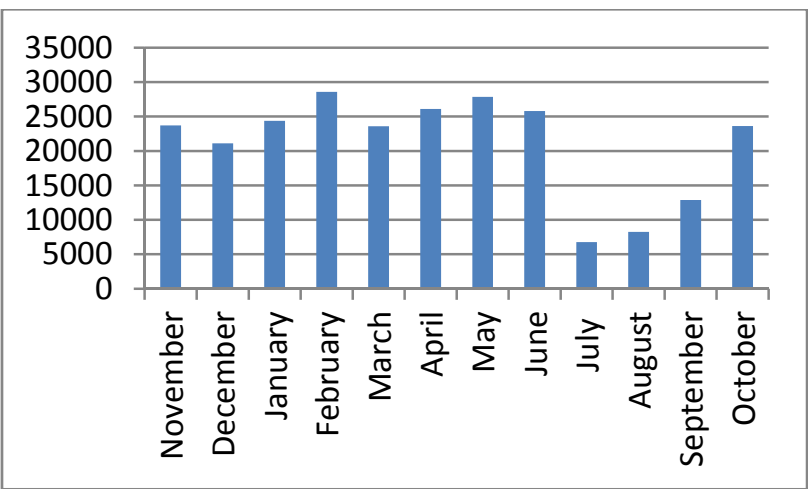

Fig. 4 Monthly Solar Power Generation 
Table 3 Diesel Consumption after the SPV integration

\begin{tabular}{|c|c|c|c|c|}
\hline $\begin{array}{c}\text { S. } \\
\text { No }\end{array}$ & Month & $\begin{array}{c}\text { Diesel } \\
\text { Consumption } \\
\text { (liter) }\end{array}$ & $\begin{array}{c}\text { Total } \\
\text { Number of } \\
\text { Diesel } \\
\text { Units }\end{array}$ & $\begin{array}{c}\text { Total } \\
\text { Cost of } \\
\text { Diesel } \\
\text { (Rs) }\end{array}$ \\
\hline 1 & October & 2349 & 6358 & 150899 \\
\hline 2 & November & 381 & 765 & 23081 \\
\hline 3 & December & 387 & 592 & 23444 \\
\hline 4 & January & 326 & 521 & 19749 \\
\hline 5 & February & 401 & 651 & 24293 \\
\hline 6 & March & 375 & 780 & 22718 \\
\hline 7 & April & 888 & 2446 & 48786 \\
\hline 8 & May & 569 & 975 & 31261 \\
\hline 9 & June & 507 & 1131 & 27854 \\
\hline 10 & July & 440 & 835 & 23883 \\
\hline 11 & August & 464 & 752 & 25186 \\
\hline 12 & September & 569 & 1318 & 30885 \\
\hline
\end{tabular}

The total number of units produced by the diesel generators in the period considered from the above table is 17,124 . The quantity of diesel consumed in this period was 7656 liters. The total expenditure on diesel during this period is Rs.4, 52,039/-.

\section{DIESEL VS SOLAR POWER GENERATION}

The considered system has two alternative power supplying means namely Diesel Generator and Solar Photo Voltaic System in addition to the state electricity board supply. Diesel Generators can be operated in an islanded mode to meet the entire load in the event of forced/Scheduled outages. SPV can take only a percentage of the total load along with either Diesel Generator or utility. The load requirements are met by the SPV and utility under normal conditions and by the SPV and diesel generators in the event of scheduled/forced outages. Thus load on utility and diesel generators are reduced after the installation of SPV.

This results in a reduction of diesel bill and utility bill. Utility bill and Diesel bill before and after SPV installation are presented in Table 4. Fig. 5 shows the reduction in utility bill and Diesel bill before and after the installation of SPV and Fig. 6 represents the reduction in the number of Diesel Generator units generated before and after SPV.

Table 4 Diesel and Utility Bill before and after SPV

\begin{tabular}{|c|c|c|c|c|}
\hline Month & \multicolumn{2}{|c|}{ Utility Bill (Rs) } & \multicolumn{2}{c|}{ Diesel Cost (Rs) } \\
\hline & $\begin{array}{c}\text { Before } \\
\text { SPV }\end{array}$ & $\begin{array}{c}\text { After } \\
\text { SPV }\end{array}$ & $\begin{array}{c}\text { Before } \\
\text { SPV }\end{array}$ & After SPV \\
\hline October & 437499 & 131562 & 112168 & 150899 \\
\hline November & 432066 & 217117 & 46056 & 23081 \\
\hline December & 389218 & 134731 & 62084 & 23444 \\
\hline January & 372490 & 129121 & 17278 & 19749 \\
\hline February & 434770 & 135455 & 85827 & 24293 \\
\hline March & 422080 & 190943 & 109964 & 22718 \\
\hline April & 422472 & 247391 & 108593 & 48786 \\
\hline May & 458305 & 258353 & 73074 & 31261 \\
\hline June & 429125 & 209259 & 78633 & 27854 \\
\hline July & 339837 & 173195 & 84447 & 23883 \\
\hline August & 368024 & 340609 & 139795 & 25186 \\
\hline September & 286433 & 321678 & 55422 & 30885 \\
\hline
\end{tabular}

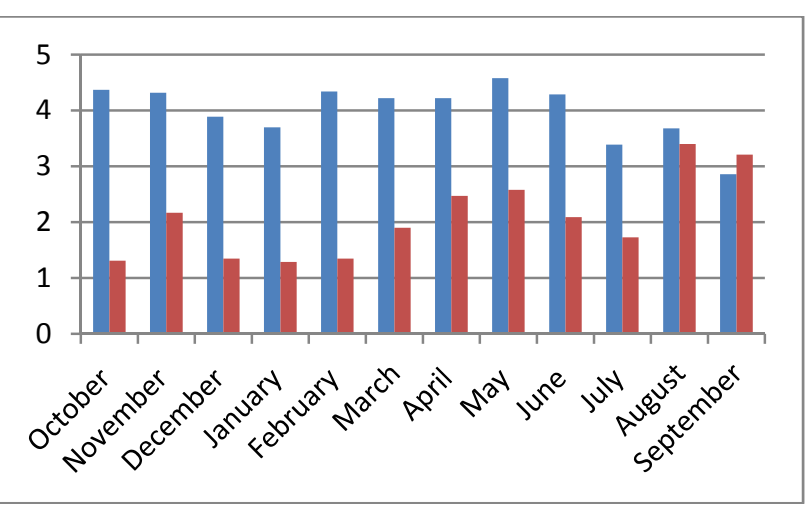

Fig. 5 Utility bill before and after SPV

The first column of the figure represents the utility bill before the installation of SPV and the second column is the utility bill after the installation of SPV.

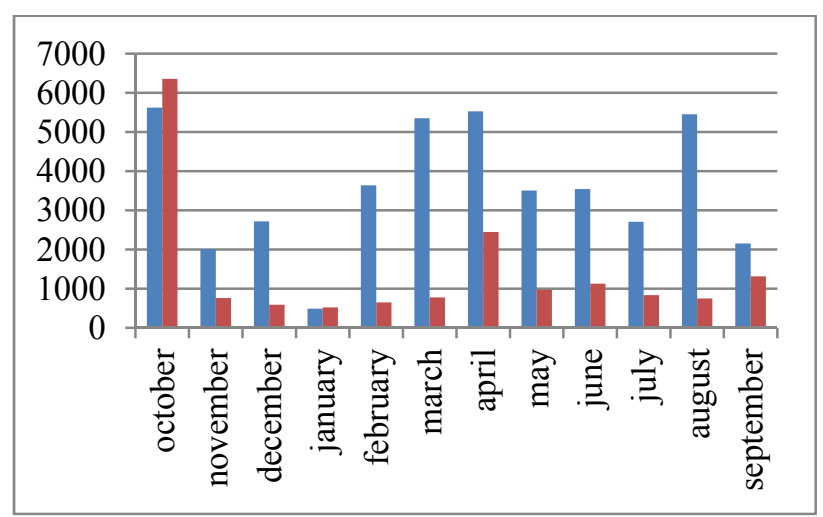

Fig. 6 Number of Diesel Units Generated before and after SPV

The first column of the figure represents the Diesel units $(\mathrm{kWh})$ before the installation of SPV and the second column is the Diesel units $(\mathrm{kWh})$ after the installation of SPV.

Diesel Generator has can take the total load of the college alone and its generation is independent but it suffers from the disadvantage that its operation cost is very high and its operation is not free form pollution. The Solar Photovoltaic system can take only a partial load of the system and it has to be operated in integrated mode with the utility and in the absence of the load the generated units are fed to the grid generating revenue. Reduction in the maximum demand agreement and the clean energy production were the additional benefits.

Diesel Generators have high capital costs and running cost. No reduction in the connected load can be obtained as diesel generators operated in the event grid unavailability. Before the installation of SPV the diesel generators were used to meet the load and thus energy charges over a year include diesel consumption charges and utility bill. After the installation of SPV the diesel generators usage is considerably reduced. The energy charges before and after the installation of SPV are compared and the comparison of charges in the two cases is given in Table 5 . 
Table 5 Comparison of energy charges before and after SPV

\begin{tabular}{|c|c|c|c|c|}
\hline $\begin{array}{c}\text { S. } \\
\text { No }\end{array}$ & Category & $\begin{array}{c}\text { Before } \\
\text { SPV(Rs) }\end{array}$ & $\begin{array}{c}\text { After } \\
\text { SPV(Rs) }\end{array}$ & $\begin{array}{c}\text { Percentage } \\
\text { Reduction }\end{array}$ \\
\hline 1 & $\begin{array}{c}\text { Connected } \\
\text { Load/Max } \\
\text { imum } \\
\text { Demand } \\
\text { Charges }\end{array}$ & $1,68,000$ & 84000 & 50.00 \\
\hline 2 & $\begin{array}{c}\text { Utility } \\
\text { Bill }\end{array}$ & $42,92,319$ & $24,89,413$ & 42.00 \\
\hline 3 & $\begin{array}{c}\text { Diesel } \\
\text { Consumpt } \\
\text { ion } \\
\text { Charges }\end{array}$ & $9,73,341$ & $4,52,039$ & 53.55 \\
\hline 4 & $\begin{array}{c}\text { Total } \\
\text { Energy } \\
\text { Bill }\end{array}$ & $52,65,660$ & $29,41,452$ & 44.13 \\
\hline \multicolumn{3}{|c|}{} \\
\hline
\end{tabular}

\section{CONCLUSIONS}

In this work the case study of a distribution system containing two types of distributed generation is considered and compared. When Diesel Generator is present as an alternate power supply the energy expenditure was Rs.52,65,660/-. When solar is added to the system as the second alternate power supply the fixed charges corresponding to maximum demand and the amount of diesel utilized are reduced. In addition the above two advantages, being a grid integrated SPV system in the absence of load demand, and the generated units were exported to the grid generating revenue. Thus the total energy charges considering the solar photo voltaic system were Rs.29,41,452/- resulting a reduction of $44 \%$ in the total energy bill. This work presents the advantage of SPV over Diesel generator in terms of operating cost and can be helpful in determining the size of SPVs for installation.

\section{ACKNOWLEDGMENTS}

I would like to express sincere thanks to Vasavi College of Engineering for providing the required data for the analysis.

\section{REFERENCES}

[1] SHORT, T. A.: Electric Power Distribution Handbook, CRC Press, 2014.

[2] CHIRADEJA, P. - RAMAKUMAR, R.: An approach to quantify the technical benefits of distributed generation, IEEE Transactions on energy conversion, Vol. 19, Issue 4, 2004, pp. 764-773.

[3] BORGES, C. L. T. - FALCÃO, D. M.: Impact of distributed generation allocation and sizing on reliability, losses and voltage profile, In Power Tech Conference Proceedings, 2003 IEEE Bologna, Vol. 2, 2003.

[4] PEPERMANS, G. - DRIESEN, J. HAESELDONCKX, D. - BELMANS, R. D'HAESELEER, W.: Distributed generation: definition, benefits and issues, Energy Policy, Vol. 33, Issue 6, 2005, pp. 787-798.

[5] BARKER, P. - DE MELLO, R. W.: Determining the impact of distributed generation on power systems. I. Radial Distribution systems, In Power Engineering Society Summer Meeting, 2000, IEEE, Vol. 3, pp. 1645-1656.

[6] KAUHANIEMI, K. - KUMPULAINEN, L.: Impact of distributed generation on the protection of distribution networks, 2004, pp. 315-318.

[7] PECAS LOPES, J. A. - HATZIARGYRIOU, N. MUTALE, J. - DJAPIC, P. - JENKINS, N.: Integrating distributed generation into electric power systems: A review of drivers, challenges and opportunities, Electric power systems research 77, 2007, pp. 1189-1203.

[8] EL-KHATTAM, W. - BHATTACHARYA, K. YASSER HEGAZY, Y. - SALAMA, M. M. A.: Optimal investment planning for distributed generation in a competitive electricity market, IEEE Transactions on Power Systems, Vol. 19, No. 3, 2004, pp. 1674-1684.

Received June 2, 2017, accepted September 11, 2017

\section{BIOGRAPHIES}

Ch. V. S. S. Sailaja is currently working as an Associate Professor in the Department of Electrical and Electronics Engineering at Vasavi College of Engineering affiliated to Osmania University, Hyderabad, India. She has been graduated in Electrical \& Electronics Engineering from Jawaharlal Nehru Technological University, Hyderabad and received M.Tech in Electrical Power Engineering from Jawaharlal Nehru Technological University, Hyderabad, India. Her areas of interest are Power Distribution Systems, Distributed Generation and Reliability Engineering.

Dr. P. V. N. Prasad is currently working as a Professor in the Department of Electrical Engineering at University College of Engineering in Osmania University, Hyderabad, India. He has been graduated in Electrical \& Electronics Engineering from Jawaharlal Nehru Technological University, Hyderabad and received M.E in Industrial Drives \& Control from Osmania University, Hyderabad, India. He received his Ph.D in Electrical Engineering in 2002. His areas of interest are Simulation of Electrical Machines \& Power Electronic Drives and Reliability Engineering. He is a member of Institution of Engineers (India) and Indian Society for Technical Education. He is the recipient of Dr. Rajendra Prasad Memorial Prize from Institution of Engineers (India) in 1993-94 for best paper. He has got over 110 publications in National and International Journals, Magazines, Conferences \& Symposia and presented technical papers in Thailand, Italy and U.S.A. 